\title{
Acetic acid tolerance in wood- and litter-decomposing Hymenomycetes
}

\author{
Veikko Hintikka
}

Finnish Forest Research Institute

\section{Introduction}

Wood, whether living or decomposing, forms a complicated and changing system, in which the various chemical and biotic factors which affect the fungus mycelium within the wood can only be elucidated with difficulty. Among these factors, the acidity of the wood depends to a considerable degree on the presence of volatile acids, the most important of which are acetic and formic acids. According to Packman (1960), the content of total free acids, mostly acetic acid, in fresh oak wood may be up to $0.45 \%$ of the dry weight, in birch wood $0.09 \%$, in beech $0.10 \%$, and in Douglas fir $0.11 \%$. It is these acids that are responsible for the corresive action of the wood of certain trees, especially oak and sweet chestnut, on metals, particularly lead, in which a chain reaction from acetic acid to lead carbonate sets in (FARMer 1967).

Owing to the presence of free acids, the $\mathrm{pH}$ of fresh wood may often be quite low. According to the data of Gray (1958), the acidity of hardwoods varies between $\mathrm{pH} 2.75$ and 6.8, and among European species the most acid are the oaks ( $\mathrm{pH} 3.35)$. Fraxinus excelsior ( $\mathrm{pH} 3.55)$, and Castanea sativa ( $\mathrm{pH} 4.0$ ), while values between $\mathrm{pH} 4.0$ and 5.0 are common. The $\mathrm{pH}$ of softwoods varies between 2.7 (Pinus strobus) and 8.8, the acidity of the wood of Picea excelsa being 4.75 and that of Pinus silvestris 4.75-5.25 (GRAY 1958).
When wood is hydrolyzed in boiling dilute sulfuric acid, acetic acid is liberated in considerable amounts from the acetyl groups of the wood, and it is one of the major products of the dry distillation of wood. In conifer wood, acetyl groups are mainly associated with galactoglucomannans and in hardwoods with 4-0 methylglucuranoxylan, the yield of acetic acid in the former being $0.5-2 \%$, and in hardwoods considerably higher, 2-6 \% (KLINGSTEDt 1937, HäGGLund 1951).

According to Packman (1960), acetic acid develops in wood, when kept under damp conditions at $48^{\circ} \mathrm{C}$, and a corresponding amount of acetyl groups is lost from the wood. In his experiments the amount of total free acid, mostly acetic acid, increased during two years' storage in birch wood from $0.9 \%$ to $2.4 \%$, in oak wood from $0.4 \%$ to $6.5 \%$, and in Sitka spruce from $0.02 \%$, to $1.6 \%$, if the samples were not contaminated with micro-organisms. Correspondingly, the $\mathrm{pH}$ of the birch wood decreased from 4.6 to 3.32 in 126 days.

Stewart et al. (1961) have found evidence that acid hydrolysis occurs within the living tree, probably owing to the formation of acetic acid from acetyl groups. To begin with, this autocatalytic process takes place very slowly, but the acetic acid liberated causes additional hydrolysis and formation of more acid over long periods of time. There is a parallel lowering in the $\mathrm{pH}$ of the wood, e.g. in Eucalyptus from $\mathrm{pH} 4.6$ in 5-year-old sapwood to $\mathrm{pH} 3.3$ in 420 -year-old heartwood. 
Similarly, young sapwood of Larix occidentalis contains only a small amount of acetic acid $(0.039 \%)$, but this causes slow additional liberation of acetic acid by hydrolysis resulting in a content of $0.14 \%$ acetic acid in heartwood 320 years old (CoTE et al. 1961).

Fungi and other micro organisms growing within wood may inhibit this accumulation, probably by consuming the acid (PAckMan 1960). On the other hand, acetic acid is a common metabolite in fungus cultures and numerous species are known to produce it (Cochrane 1958); among the wood-decomposing fungi it is produced by Polyporus species from carbohydrates (PerLman 1949, 1950) and by Fomes annosus. In addition, many bacteria produce acetic acid (WAKSMAN 1931) e.g. from cellulose (Sru 1951). In thermophilic bacterial attack on wood components the main products are acids, such as acetic, butyric, and lactic acids (VIRTANEN \& HukkI 1946).

Adequate information is not available to allow a comparison of the occurrence of acetic acid in other types of natural substrates. According to ScHwartz et al. (1954), acetic acid may be present in podzol soils in quantities of 0.73 to $1.08 \mathrm{meq}$ per $100 \mathrm{~g}$ soil, the content being thus lower than in wood. In flooded soils the content of acetic acid may be to $3 \times 10^{-3} \mathrm{meq} / \mathrm{ml}$ (Hollis \& RoDRIQUEz 1967) and this acid evidently plays a role in the microbiology of flooded soils (AleXander 1961). If acetate is added to the soil, it is metabolized rather rapidly by the soil microbial population (STEvenson \& KATZNELSON 1958).

Thus, on the basis of the literature, it seems that acetic acid may accumulate in wood and affect the mycelia growing within it. In the present investigation, the tolerance of certain wood-decomposing and litter-inhabiting basidiomycetes to acetic acid was studied.

\section{Methods}

Fungus strains were cultivated on Hagem agar, the composition of which is: glucose $5 \mathrm{~g}$, malt extract $5 \mathrm{~g}, \mathrm{KH}_{2} \mathrm{PO}_{4} 0.5 \mathrm{~g}, \mathrm{MgSO}_{4} \cdot 7 \mathrm{H}_{2} \mathrm{O} 0.5 \mathrm{~g}$, $\mathrm{NH}_{4} \mathrm{Cl} 0.5 \mathrm{~g}, \mathrm{FeCl}_{3}(1 \%$ sol. $) 1 \mathrm{ml}$, agar $15 \mathrm{~g}$ and distilled water 11 . After this mixture had been autoclaved for $20 \mathrm{~min}$. at $120^{\circ} \mathrm{C}$, measured amounts of sterile acetic acid were added with a pipet, and the agar poured in to $10 \mathrm{~cm}$ petri dishes. The radial growth was measured after a variable number of days $(7-10)$ and thus the differences in the growth rates between the species are not comparable.

The strains used in this investigation were isolated in the years 1964-67, and preserved at the laboratory of the Forest Biology Department, Finnish Forest Research Institute, at $5^{\circ} \mathrm{C}$ with transfers about twice a year.

As the content of phosphate was rather high, it buffered the changes in $\mathrm{pH}$ brought about by the acid to some degree. The $\mathrm{pH}$ of the different concentrations were: $0 \%: 4.8,0.01 \%: 4.7,0.05$ $\%: 4,0,3: 1 \%: 3.8,0.2 \%: 3.6$, and $0.3 \%: 3.4$. These $\mathrm{pH}$ values agree fairly well with the values given above for natural wood containing acetic acid.

\section{Results}

The soil hymenomycetes investigated proved to be rather sensitive to acetic acid (Table 1 and Fig. 1). The growth of typical litter-decomposing as well as mycorrhizal species (Clitocybe, Collybia, Suillus) was totally inhibited by concentrations of $0.01 \%$. More tolerant were Clavaria fistulosa, $M a$ rasmius androsaceus, and species of Pholiota, many of which in nature show a distinct preference for twigs, small pieces of wood or bark heaps, although they do not as a rule grow directly on thick logs.

In general, fungi growing on conifer wood were considerably more tolerant to acetic acid, some of them growing at $0.1 \%$, namely Fomitopsis pinicola, Gloeophyllum sepiarium, Phaeolus schweinizii, Abortiporus borealis, Anisomyces odoratus, and Stereum sanguinolentum. These species are characteristic of thick logs of stumps or living stems of conifers. Stereum sanguinolentum occurs as a heart-rot parasite in living spruces, although it does not form besidiocarps on this substrate. Species growing on old decayed wood of conifers, such as Xeromphalina campanella and Flammula penetrans, showed a markedly lower tolerance of acetic acid, the maximum being approximately the same as that of the most tolerant species of the litter-decomposing group.

In species growing in nature on deciduous wood the tolerance was fairly similar to that of the conifer wood species, or even higher. Especially it should be noted that the species occurring on thick trunks of oak (Daedalea 
quercina, Laetiporus sulphureus) or elm (Tyromyces fissitis) still grew fairly well at $0.2 \%$, a concentration at which all the other species investigated failed to grow. Oak wood especially is known to contain considerable amounts of acetic acid (FARMer 1967).

\section{Discussion}

That acetic acid may have an ecological significance in the biology of wood-decomposing fungi is indicated by the experiments of Suolahti (1951), who found that it exerts a stimulatory effect on the aerial mycelium of Stereum sanguinolentum. As acetic acid is one of the central metabolites in fungal metabolism, e.g. in the TCA cycle and in the synthesis of many compounds, it would be interesting to investigate to what extent the enzyme systems of lignicolous fungi differ form those of the litter-decomposing species. The present experiments suggest a distinct difference in this respect between the two ecological groups.

When the values given for concentrations of acetic acid in wood and in soil are compared with the above values in the agar substrate, it should be noted that the former are based on the dry weight, and the actual concentration of the cid in the liquid phase may be different, depending of the moisture content, although exact determinations seem to be lacking. In any case the present experiments indicate that the tolerance, especially of species attacking oak wood, may be of considerable ecological importance.

Wood is denser in structure than soil, and the soluble and volatile substances within it are not exposed to leaching with rain water or evaporation to a same extent as in soil. Forest soils, especially, are comparatively well ventilated and, for instance, the carbon dioxide concentration does not as a rule exceed $1-2 \%$, although in wood it often rises to 10-15\% (Thacker \& Good 1952). Thus it is possible, although not conclusively proved, that acetic acid accumulates in wood in greater quantities than in soil, and may thus, like many other chemical factors, exert a selective effect on the invading microbial population.

In connection with the present experiments some attempts were made to isolate lignicolous fungi from forest soils with $0.3 \%$ acetic acid-Hagem-agar dilution plates. There were great differences in the fungus flora between the plates containing acid and those without acid. In Hagem agar many species of $M u c o r$ as well as other Phycomycetes species were present, but in acetic agar species of Penicillium totally dominated the plates and inhibited any mycelia of lignicolous basidiomycetes possibly present.

\section{Summary}

On the basis of a literature review, acetic acid may occur in wood from three different origins: 1) as free acid, especially in oak wood, 2) liberated through hydrolysis from acetyl groups of wood, and 3) metabolic products of micro-organisms. The content of acetic acid in the wood of living trees may exceed $0.4 \%$ per unit of dry weight.

The tolerance of 125 species of basidiomycetes was determined by adding sterile acetic acid to Hagem agar after autoclaving, and the radial growth of mycelia was measured after 7-10 days. The $\mathrm{pH}$ of the acid agar agreed fairly well with the values given for wood containing acetic acid.

The typical litter-decomposing species were found to tolerate $0.01 \%$ acetic acid or below, while species which in nature occur on small branches or twigs grew in slightly higher concentrations. Species growing on conifer wood tolerated as much as $0.1 \%$, the highest tolerance being observed in species which grow in thick logs or within living tree stems. Among species attacking deciduous wood, the highest tolerance $(0.2-0.3 \%)$ was found in the fungi which occur in living oaks and elms (Daedalea quercina, Laetiporus sulphureus).

The ecological significance of this difference is discussed and the possible accumulation of acetic acid and other metabolic products in wood due to its compact structure compared with easily leachable forest humus and litter is emphasized.

$$
\text { A c know led g ments }
$$

The author expresses his thanks to Mr. LALLI LAINE, M.Sc., for allowing the use of 15 strains of polypores determined and isolated by him.

Financial support by U.S. Public Law 480 grant Fg-Fi-132 is gratefully acknowledged.

Received 30. 5. 1969. 
Table 1. The effect of acetic acid on the radial growth (mm) of some hymenomycetes.

\section{Soil fungi}

\begin{tabular}{|c|c|c|c|c|c|c|}
\hline Species & 0 & 0.005 & 0.01 & 0.025 & 0.05 & 0.075 \\
\hline Agaricus sp. & 13 & 10 & 0 & 0 & 0 & 0 \\
\hline Agrocyge praecox & 10 & 12 & 10 & 1 & 0 & 0 \\
\hline Ascobolus sp. & 18 & - & 10 & 0 & 0 & 0 \\
\hline Glitocybe clavipes & 12 & 9 & 4 & 0 & 0 & 0 \\
\hline C. nebularis & 11 & 13 & 2 & 0 & 0 & 0 \\
\hline C. odora & 5 & 5 & 1 & 0 & 0 & 0 \\
\hline C. phyllophila & 4 & 3 & 2 & 0 & 0 & 0 \\
\hline Clitopilus prunulus & 6 & 5 & 4 & 0 & 0 & 0 \\
\hline Clavaria fistulosa & 8 & - & 7 & 4 & 0 & 0 \\
\hline Collybia asema & 19 & 13 & 0 & 0 & 0 & 0 \\
\hline C. butyracea & 10 & 7 & 0 & 0 & 0 & 0 \\
\hline C. confluens & 11 & 10 & 8 & 0 & 0 & 0 \\
\hline C. dryophila & 20 & 19 & 0 & 0 & 0 & 0 \\
\hline C. peronata & 12 & 11 & 8 & 0 & 0 & 0 \\
\hline C. putilla & 15 & 11 & 10 & 3 & 0 & 0 \\
\hline Cystoderma amianthina & 8 & 2 & 1 & 0 & 0 & 0 \\
\hline C. granulosa & 1 & 1 & 0 & 0 & 0 & 0 \\
\hline Galerina paludosa & 7 & 3 & 0 & 0 & 0 & 0 \\
\hline Hygrophoropsis aurantiaca & 6 & 4 & 2 & 0 & 0 & 0 \\
\hline Lepiota clypeolaria & 11 & 11 & 11 & 6 & 0 & 0 \\
\hline Lepista nuda & 9 & 11 & 7 & 0 & 0 & 0 \\
\hline Lycoperdon pyriforme & 10 & 10 & 5 & 0 & 0 & 0 \\
\hline Macrolepiota rhacodes & 6 & - & 0 & 0 & 0 & 0 \\
\hline Marasmius androsaceus & 24 & 21 & 18 & 13 & 0 & 0 \\
\hline M. epiphyllus & 5 & 5 & 3 & 0 & 0 & 0 \\
\hline$M$. oreades & 10 & 6 & 5 & 0 & 0 & 0 \\
\hline M. prasiosmus & 10 & 10 & 6 & 0 & 0 & 0 \\
\hline M. rotula & 25 & 10 & 22 & 7 & 0 & 0 \\
\hline M. scorodonius & 27 & 26 & 25 & 15 & 0 & 0 \\
\hline Micromphale perforans & 16 & 15 & 13 & 8 & 0 & 0 \\
\hline Mycena epipterygia & 14 & 14 & 12 & 6 & 0 & 0 \\
\hline M. galopus & 7 & 5 & 5 & 1 & 0 & 0 \\
\hline M. sanguinolenta & 11 & 9 & 7 & 0 & 0 & 0 \\
\hline M. viscosa & 6 & - & 5 & 0 & 0 & 0 \\
\hline Panaeolus sp. & 5 & - & 3 & 2 & 0 & 0 \\
\hline Phaeolepiota aurea & 3 & 4 & 1 & 0 & 0 & 0 \\
\hline Pholiota carbonaria & 41 & 40 & 42 & 36 & 12 & 0 \\
\hline P. lenta & 16 & 16 & 15 & 13 & 7 & 0 \\
\hline P. lubrica & 23 & 25 & 23 & 23 & 11 & 0 \\
\hline P. spumosa & 15 & 13 & 13 & 13 & 0 & 0 \\
\hline Psathyrella gracilis (?) & 5 & 10 & 7 & 0 & 0 & 0 \\
\hline Rhizopogon sp. & 8 & - & 0 & 0 & 0 & 0 \\
\hline Stropharia aeruginosa & 12 & 16 & 12 & 15 & 0 & 0 \\
\hline S. hornemannii & 3 & 3 & 2 & 1 & 0 & 0 \\
\hline S. semiglobata & 11 & 10 & 8 & 7 & 0 & 0 \\
\hline Suillus bovinus & 15 & - & 0 & 0 & 0 & 0 \\
\hline S. elegans & 3 & 6 & 0 & 0 & 0 & 0 \\
\hline S. variegatus & 19 & 7 & 0 & 0 & 0 & 0 \\
\hline
\end{tabular}


Table 1 (cont.). Fungi growing on deciduous wood

\begin{tabular}{|c|c|c|c|c|c|c|c|c|c|}
\hline Species & isolated from & 0 & 0.005 & 0.01 & 0.025 & 0.05 & 0.075 & 0.1 & 0.2 \\
\hline Aporpium semisupinum & Betula & 21 & - & - & 20 & 4 & 0 & 0 & 0 \\
\hline Armillaria mellea & Quercus & 5 & - & 6 & 5 & 4 & 0 & 0 & 0 \\
\hline$\ll \quad \ll$ & Salix frag. & 5 & - & 5 & 6 & 5 & 0 & 0 & 0 \\
\hline Bjerkandera adusta & Betula & 29 & 29 & 32 & 20 & 12 & 8 & 8 & 0 \\
\hline Coriolus hirsutus & Betula & 40 & $\overline{10}$ & 38 & 38 & 30 & 22 & 14 & 0 \\
\hline Daedalea quercina & Quercus & 18 & 19 & 19 & 19 & 18 & 一 & 14 & 11 \\
\hline Daedaleopsis confragosa & & & & & & & & & \\
\hline v. tricolor & Betula & 12 & - & $\overline{0}$ & 12 & 0 & 0 & 0 & 0 \\
\hline Flammula alnicola & Betula & 20 & - & 20 & 18 & 15 & 9 & 6 & 0 \\
\hline F. sp. & Betula & 18 & 一 & 19 & 10 & 16 & 10 & 8 & - \\
\hline Fla:imulina velutipes & Populus & 45 & 一 & 45 & 33 & 6 & 0 & 0 & 0 \\
\hline Fomes fomentarius & Betula & 34 & 一 & 35 & 18 & 10 & 0 & 0 & 0 \\
\hline Fomitopsis pinicola & Betula & 29 & 一 & 一 & 一 & 20 & 17 & 15 & 0 \\
\hline$\ll$ & Tilia & 34 & 一 & - & 一 & 23 & 17 & 16 & 0 \\
\hline$\ll$ & A. incana & 27 & - & - & - & 22 & 16 & 13 & 0 \\
\hline F. odoratissima & Salix & 3 & 4 & 4 & 2 & 0 & 0 & 0 & 0 \\
\hline Ganoderma applanatum & - & 8 & 13 & 9 & 10 & 1 & 0 & 0 & 0 \\
\hline G.lucidum & A. glutinosa & 10 & 9 & 9 & 5 & 4 & 0.5 & 0 & 0 \\
\hline Gloeoporus dichrous & Betula & 19 & 一 & - & 15 & 6 & 2 & 0 & 0 \\
\hline Hapalopilus nidulans. & Betula & 7 & 一 & 10 & 8 & 1 & 0 & 0 & 0 \\
\hline Hohenbuehelia serotina & Betula & 41 & - & 40 & 34 & 28 & 21 & 14 & 0 \\
\hline Hydnum septentrionale & A. glutinosa & 6 & 9 & 8 & 23 & 18 & 4 & 0 & 0 \\
\hline Hymenochaete rubiginosa & Quercus & 4 & 4 & 5 & 3 & 0 & 0 & 0 & 0 \\
\hline Hypholoma fasciculare & - & 10 & 一 & 9 & 9 & 4 & 0 & 0 & 0 \\
\hline H. sublateritium & Betula & 22 & 21 & 21 & 20 & 0 & 0 & 0 & 0 \\
\hline Inonotus obliquus & Betula & 19 & 21 & 22 & 14 & 1 & 0 & 0 & 0 \\
\hline I. radiatus & A. glutinosa & 11 & 一 & 一 & 15 & 4 & 0 & 0 & 0 \\
\hline I. rheades & Populus & 11 & - & 16 & 17 & 13 & 5 & 0 & 0 \\
\hline Lentinus bisus & Betula & 25 & 22 & 24 & 24 & 7 & 0.5 & 0 & 0 \\
\hline L. vulpinus (?) & Betula & 25 & 一 & 25 & 24 & 13 & 4 & 1 & 0 \\
\hline Lentinus sp. & Betula & 18 & - & 20 & 15 & 5 & 0 & 0 & 0 \\
\hline Lenzites betulina & Betula & 37 & 40 & 40 & 39 & 14 & 4 & 12 & 0 \\
\hline Laetiporus sulphureus & Quercus & 16 & 一 & $\overline{-}$ & 38 & 37 & 33 & 25 & 16 \\
\hline Lyophyllum ulmarium & Acer platanoides & 19 & - & 17 & 9 & 3 & 0 & 0 & 0 \\
\hline Panellus stypticus & Quercus & 14 & 11 & 13 & 13 & 0 & 0 & 0 & 0 \\
\hline Panus conchatus & Betula & 13 & 一 & 13 & 12 & 10 & 1 & 0 & 0 \\
\hline Phellinus conchatus & Salix caprea & 26 & 30 & 26 & 23 & 19 & 15 & 11 & 0 \\
\hline P. ferruginosus & Corylus & 21 & 18 & 13 & 9 & 0 & 0 & 0 & 0 \\
\hline P. igniarius & Betula & 20 & 22 & 22 & 19 & 0 & 0 & 0 & 0 \\
\hline P. pomaceus & Prunus ceraceus & 20 & 23 & 22 & 20 & 0 & 0 & 0 & 0 \\
\hline P.punctatus & Salix caprea & 9 & - & 7 & 6 & 0 & 0 & 0 & 0 \\
\hline \multirow[t]{2}{*}{ P. robustus v. hippophaes } & Hippophae & & & & & & & & \\
\hline & rhamnoides & 7 & 7 & 7 & 2 & 0 & 0 & 0 & 0 \\
\hline P. tremulae & Populus & 3 & 4 & 7 & 5 & 3 & 0 & 0 & 0 \\
\hline Pholiota aurivella & Acer & 18 & - & 19 & 19 & 17 & 10 & 8 & 0 \\
\hline P. mutabilis & Betula & 23 & 23 & 19 & 16 & 0 & 0 & 0 & 0 \\
\hline P. squarrosa & decid. tree & 19 & - & 19 & 18 & 15 & 一 & 9 & 0 \\
\hline Phyllotopsis nidulans & Betula & 22 & 24 & 22 & 25 & 15 & 1 & 0 & 0 \\
\hline Piptoporus betulinus & Betula & 26 & 27 & 34 & 33 & 10 & 8 & 0 & 0 \\
\hline Pleurotus ostreatus & Aesculus & 45 & - & 38 & 31 & 7 & 0 & 0 & 0 \\
\hline Polypilus frondosus & Quercus & 26 & 34 & 37 & 40 & 26 & 0 & 8 & 0 \\
\hline Polyporus brumalis & - & 28 & 29 & 30 & - & 21 & 14 & 9 & 0 \\
\hline P. squamosus & Ulmus & 10 & 10 & 10 & 0.5 & 0 & 0 & 0 & 0 \\
\hline P. varius & Tilia & 19 & 20 & 18 & 12 & 0 & 0 & 0 & 0 \\
\hline Pycnoporus cinnabarinus & Sorbus & 22 & 一 & - & 21 & 16 & 11 & 7 & 0 \\
\hline Stereum hirsutum & Betula & 26 & - & 29 & 27 & 14 & - & 0 & 0 \\
\hline S. purpureum & Betula & 13 & - & - & 11 & 7 & 0 & 0 & 0 \\
\hline Trametes suaveolens & Salix & 40 & 40 & 35 & 25 & 13 & 0 & 0 & 0 \\
\hline Tyromyces fissilis & Ulmus & 25 & 26 & 26 & 25 & 20 & 15 & 14 & 5 \\
\hline
\end{tabular}


Table 1 (cont.). Fungi growing on conifer wood

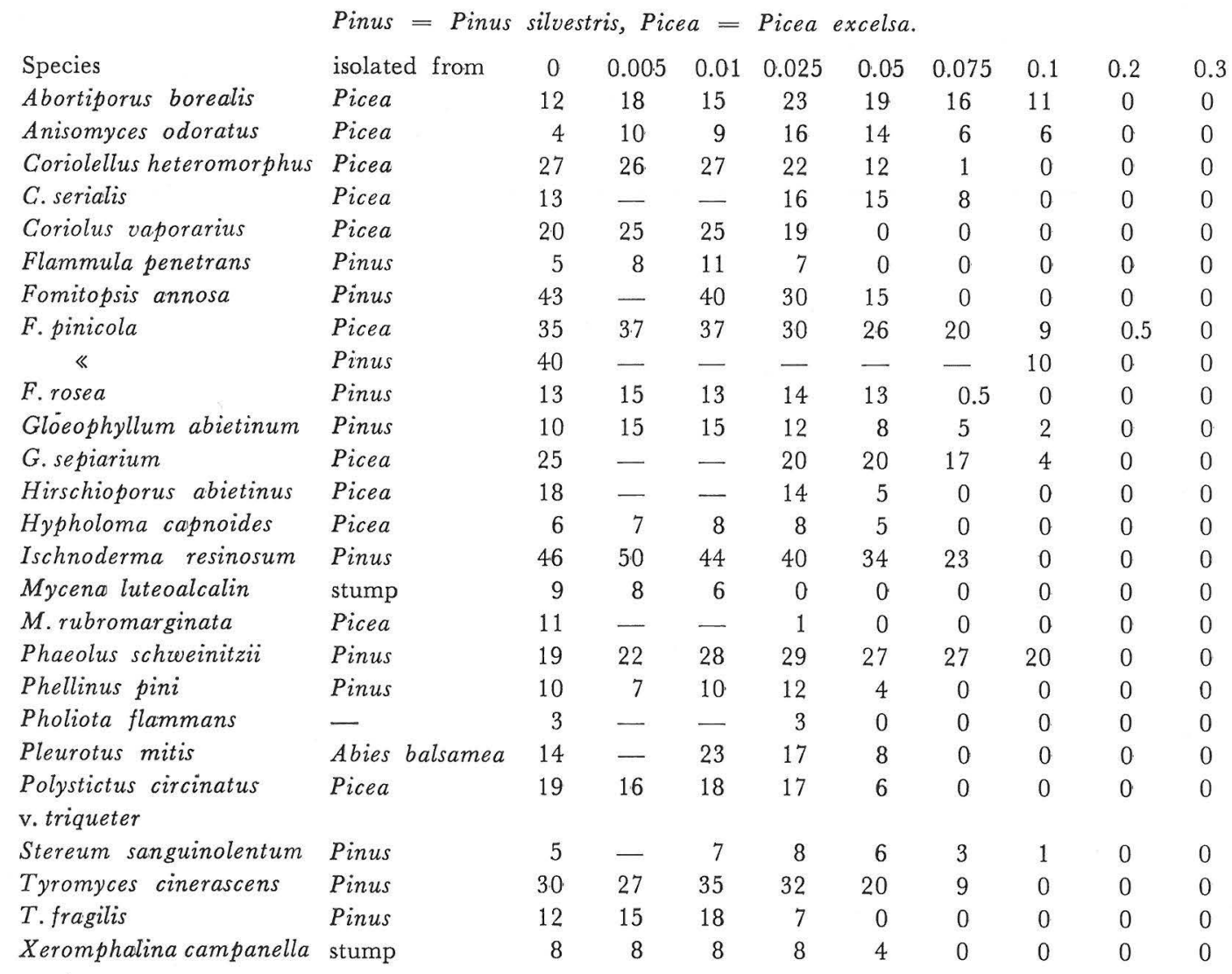

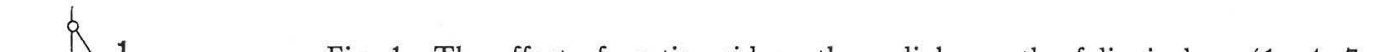

Fig. 1. The effect of acetic acid on the radial growth of lignicolous $(1-4,7-$ $10,13-14)$ and soilinhabiting $(5-6,11-12,15)$ fungi. 1: Fomitopsis annosa, 2: Hohenbuehelia serotina, 3: Coriolus hirstus, 4: Pycnoporus cinnabarinus, 5: Collybia dryophila, 6: Collybia asema, 7: Daedalea quercina, 8: Hirschioporus abietinus, 9: Panus conchatus, 10: Trametes serialis, 11: Mycena sanguinolenta, 12: Marasmius oreades, 13: Stereum sanguinolentum, 14: Hypholoma capnoides, 15: Suillus variegatus. 


\section{REFERENCES}

AleXANder, M., 1961: Introduction to soil microbiology. - 472 pp. New York \& London.

Cochrane, V. W., 1958: Physiology of fungi. 524 pp. New York - London.

Cote, W. A. Jr., B. W. Simson \& T. E. Timell, 1967: Studies on larch arabinogalactan II. - Holzforschung 21, 85-88.

FARMER, R. H., 1967: Chemistry in the utilization of wood. - 193 pp. Oxford.

Gray, V. R., 1958: The acidity of wood. Journ. Inst. Wood Sc. 1958, 58-64.

Hollis, J. P. \& R. Rodriguez, 1967: Fatty acids in Louisiana rice fields. - Phytopath. 57, $841-847$.

HäGGlund, E., 1951: Chemistry of wood. - 631 pp. New York.

Klingstedt, F. W., 1937: Über die Acidyle des Holzes. -- Suomen Kemistiseuran tiedonantoja 46, 97-117.

PaGkMan, D. F., 1960: The acidity of wood. Holzforschung 14, 178-183.

Perlman, D., 1949: Studies on the growth and metabolism of Polyporus anceps in submerged culture. - Am. Journ. Bot. 36, $180-184$.

- 1950 a: Observations on the production of ethanol by fungi and yeasts. - Ibid. 37, $237-241$.
Schwarz, S. M., J. E. Warner \& W. Martin, 1954: Separation of organic acids from several dormant and incubated soils. Soil. Sc. Soc. Am. Proc. 18, 174-177.

Siv, R. G. H., 1951: Microbial decomposition of cellulose. - 531 pp. New York.

Stewart, G. M., J. F. Kottek, H. E. Dadswell \& A. J. Watson, 1961: The process of fiber separation III. - Tappi 44, 798-813.

Stevenson, I. L. \& H. Katznelson, 1958: The oxidation of ethanol and acetate in soils. - Gan. J. Microbiol. 4, 73-79.

Suolaht, O., 1951: Über eine das Wachstum von Fäulnispilzen beschleuningende chemische Fernwirkung von Holz. - Diss. 95 pp. Helsinki.

Thacker, D. G. \& H. M. Good, 1952: The composition of air in trunks of sugar maple in relation to decay. - Can. J. Bot. 30, $475-485$.

Waksman, S., 1931: Principles of soil microbiology. - 894 pp. London.

Virtanen, A. I. \& J. Hukri, 1946: Thermophilic fermentation of wood. - Suomen Kemistilehti 19: B, 4-13. 